\title{
PENGEMBANGAN BADAN USAHA MILIK DESA DI DESA TANGGUNTITI KECAMATAN SELEMADEG TIMUR KABUPATEN TABANAN
}

\author{
I.G.P. Ratna Adi ${ }^{1}$, N.W. Siti $^{2}$, N.K. Kariyati ${ }^{3}$
}

\begin{abstract}
ABSTRAK
Kegiatan pemberdayaan masyarakat bertujuan untuk pengembangan BUMDes di Desa Tangguntiti Kecamatan Selemadeg Timur kabupaten Tabanan. Metode yang diterapkan dalam pemberdayaan masyarakat pada kegiatan program PKW adalah Pelatihan dan simulasi mengenai terapan ipeks yang dialihkan bagi masyarakat; dan Pendampingan yaitu pertemuan secara berkala antara pendamping dengan masyarakat sasaran hingga ipteks yang dialihkan dapat dilaksanakan secara mandiri oleh masyarakat. Kegiatan desiminasi ipteks dalam produksi jajan upakara telah berjalan dengan baik dan mendapatkan respon positif dari masyarakat dicirikan oleh jumlah peserta yang hadir dan keseriusan peserta dalam mengikuti pelatihan. Partisipasi aktif mitra sasaran dalam seluruh kegiatan desiminasi teknologi cukup tinggi, yaitu rata-rata sebesar 85 persen. Hasil kegiatan menunjukkan bahwa lebih dari 50\% peserta sudah menguasai teknik produksi jajan upakara secara benar, dan ada 10 peserta (30\%) sudah mampu menghasilkan produk jajan sesuai standar kualitas
\end{abstract}

Kata kunci : vermikompos, cacing tanah, pertanian ramah lingkungan.

\begin{abstract}
Community empowerment activities aim to develop BUMDes in Tangguntiti Village, Selemadeg Timur District, Tabanan Regency. The method applied in community empowerment is training and simulation of applied ipeks that are transferred to the community; and Mentoring, namely regular meetings between facilitators and target communities until the transferred science and technology can be carried out independently by the community. The dissemination of science and technology activities in the production of upakara snacks has been going well and getting a positive response from the community is characterized by the number of participants present and the seriousness of the participants in the training. The active participation of target partners in all technology dissemination activities is quite high, which is an average of 85 percent. The results of the activity showed that more than $50 \%$ of the participants had mastered the production techniques of the right way to take snacks, and there were 10 participants (30\%) who were able to produce snacks according to quality standards
\end{abstract}

Keywords: vermicompost, earthworms, environmentally friendly agriculture.

\section{PENDAHULUAN}

\footnotetext{
${ }^{1}$ Fakultas Pertanian Universitas Udayana dan e-mail : suranjaya_gede@unud.ac.id

${ }^{2}$ Fakultas Peternakan Universitas Udayana.

${ }^{3}$ Universitas Dwijendra-Denpasar
} 
Desa Tangguntiti termasuk kedalam wilah administratif Kecamatan Selemadeg Timur Kabupaten Tabanan. Penggunaan lahan yang dominan di wilayah Tangguntiti berupa ladang/tegalan yang mencapai $75,60 \%$ (1.167,55 ha), pertanian sawah $14,67 \%$, penggunaan lain sebear 7,02 \%. Struktur penduduk menurut mata pencaharian menunjukkan bahwa sebagian besar penduduk menggantungkan sumber kehidupannya di sektor pertanian ( $82 \%$ ), sektor lain yang menonjol dalam penyerapan tenaga kerja adalah perdagangan ( $4 . \%)$, sektor industri rumah tangga dan pengolahan $(2,3 \%)$, sektor jasa $(0,8 \%)$ dan sektor lainnya seperti pegawai negeri, karyawan swata dari berbagai sektor $(1,6 \%)$. Angka tersebut mengindikasikan bahwa sektor pertanian merupakan bidang startegis sehingga perlu medapatkan prioritas. Usaha tani merupakan bidang usaha di hulu, diharapkan dengan berkembangnya sistem pertanian yang berwawasan agribisnis dan agrowisata dapat menstimulasi bidang jasa dan usaha lainnya di hilir. Salah satu alternatif adalah berkembangnya industri rumah tangga pembuatan makanan khas Bali, pemasaran, dan koperasi yang pada akhirnya dapat memberikan nilai tambah pendapatan bagi masyarakat perdesaan. Kelembagaan tradisional petani yaitu subak masih sangat efektif, begitu pula ketersediaan lahan pertanian masih sangat luas.

Pengembangan sektor Hulu terdiri dari penghasil bahan baku dan pengolahan hasil yang dibentuk dalam suatu wadah organisasi KUBE (kelompok usaha bersama) yang beranggotakan individuindividu petani dan individu-individu pengolah hasil yang dapat berasal dari wanita tani/ibu-ibu PKK yang berdomisili di dusun/banjar. Di setiap dusun/banjar minimal ada satu KUBE atau koperasi yang merupakan unit usaha dari BUMDes di desa setempat. KUBE akan menghasilkan produk olahan yang sepenuhnya didampingi dan menjadi sasaran kegiatan SKPD secara terpadu, mulai dari pembentukan kelembagaan kelompok, tata kelola keuangan, penguatan permodalan, pelatihan ketrampilan SDM, dan lain-lain dalam rangka menghasilkan produk olahan yang memenuhi standar mutu yang ditetapkan. Sektor Hulu ini diproteksi secara habis-habisan melalui berbagai program dan sumber dana untuk mencegah agar usaha di sektor hulu ini tidak mengalami kerugian. BUMDes yang akan membeli produk grosiran dari kelompok Hulu wajib membeli dengan selisih harga beli dan jual secara adil dan harus dibayar tunai. Produk olahan yang telah memenuhi standar mutu dari kelompok hulu, proses selanjutnya adalah pengkemasan dan pemberian label di BUMDes. Produk yang sudah dikemas di BUMDes akan dijual ke BUMD untuk selanjutnya dipasarkan pada swalayan atau konsumen akhir. BUMDes dan BUMD dalam hal ini dikelompokkan sebagai Sektor Hilir yang berperan sebagai mata rantai pemasaran. Pembayaran dari BUMD kepada BUMDes harus dilakukan secara tunai, sedangkan BUMD boleh melakukan konyiasi dengan mitra bisnis.Pemilihan bidang usaha utama oleh BUMDes harus didasarkan.

Badan Usaha Milik Desa (BUMDes) dikelola oleh masyarakat dan pemerintahan Desa dalam upaya memperkuat perekonomian Desa dan dibentuk berdasarkan kebutuhan dan potensi Desa. Dan berdasarkan Peraturan Pemerintah No. 43 Tahun 2014 tentang Desa, pasal 1 ayat 7 yaitu " Badan Usaha Milik Desa atau BUMDes merupakan badan usaha yang seluruh atau sebagian besar modalnya dimiliki oleh Desa melalui penyertaan secara langsung yang berasal dari kekayaan Desa yang dipisahkan guna mengelola aset, jasa, pelayanan usaha lainnya untuk sebesar -besarnya kesejahteraan masyarakat Desa". Dalam rangka peningkatan kesejahteraan ekonomi masyarakat, Pemerintah Daerah memberikan bantuan sejumlah dana kepada masyarakat Desa guna merangsang masyarakat untuk ikut serta aktif dalam melaksanakan pembangunan. Namun dalam perguliran dana yang di berikan tidak sesuai yang di harapkan yaitu penunggakan dana bergulir setiap tahun meningkat.

Persoalan yang dihadapi dalam pengembangan BUMDES di Desa Tangguntiti adalah belum menunjukkan hasil yang signifikan karena masih lemahnya kelembagaan BUMDes dan belum berkembangnya usaha bersama yang menghasilkan produk olahan yang bernilai ekonomi dan disukai pasar. Selain itu, Produk olahan masyarakat yang diproduksi oleh Kelompok usaha bersama (KUBE) belum memiliki nilai kompetitif dan memenuhi standar kualitas pasar sehingga sulit dipasarkan oleh BUMDes. 


\section{METODE PELAKSANAAN}

\subsection{Metode}

Metode yang diterapkan dalam pemberdayaan masyarakat ini sebagai berikut: (1) Penyuluhan untuk membangun persepsi dan penyamaan pemahaman masyarakat sasaran mengenai inovasi yang diterapkan, (2) Pelatihan mengenai penerapan ipeks yang dikenalkan kepada masyarakat, dan (3) Pendampingan secara berkala dan berkelanjutan kepada masyarakat sasaran hingga ipteks yang dialihkan dapat dilaksanakan secara mandiri.

\section{HASIL DAN PEMBAHASAN}

Pelatihan KUBE jajanan untuk keperluan acara adat ditujukan sebagai pengembangan unit usaha BUMDes. Tema ini dipilih karena prospek usaha produksi jajanan untuk keperluan upakara sangat bagus sebagai produk komersial. Selain itu, ibu-ibu PKK sebagian besar sudah biasa membuat jajanan untuk keperluan upakara, namun belum memiliki standar kualitas yang layak jual. Pelatihan ini diikuti oleh 30 orang peserta, materi yang dilatih adalah pembuatan jajan reginang, matahari, dan uli. Selain itu, juga dilatihkan pembuatan jenis jajanan pasar. Pada kegiatan ini hibahkan 1 set peralatan pengolahan jajanan untuk keperluan acara adat kepada peserta.

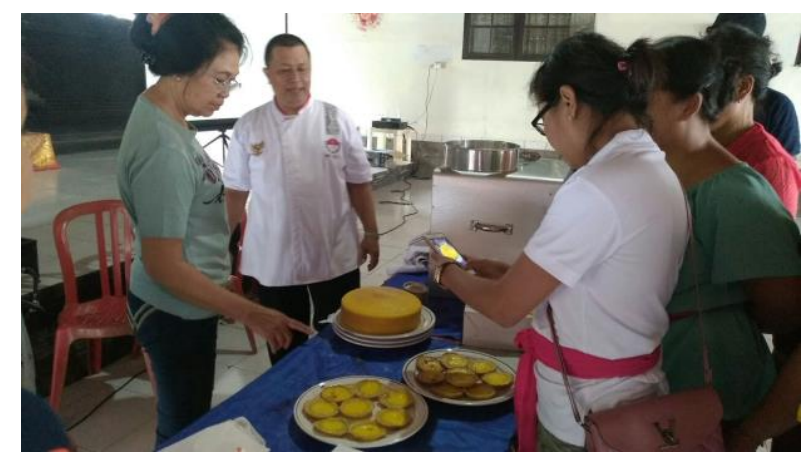

Gambar 1. Pelatihan bagi Kelompok Usaha Bersama (KUBE)

Kemajuan BUMDes sangat ditentukan oleh kualitas majemen usahanya. Oleh sebab itu, dalam pengembangan BUMDes di Desa Tangguntiti juga dilakukan pelatihan dan pendampingan manajemen. Dalam pelatihan ini dilakukan pengenalan empat fungsi dasar manajemen yaitu, Planning (Perencanaan), Organizing (Pengorganisasian), Actuating (Pelaksanaan) dan Controlling (Pengawasan). Keempat fungsi manajemen ini disingkat dengan POAC.

Perencanan adalah proses penentuan serangkaiaan tindakan untuk mencapai suatu hasil yang di inginkan dan juga proses mendefinisikan tujuan organisasi, membuat strategi untuk mencapai tujuan itu dan mengembangkan rencana aktivitas kerja organisasi. Perencanaan merupakan proses terpenting dari semua fungsi manajemen karena perencanaan maka fungsi yang lainnya tidak akan dapat berjalan. Perencanaan dalam sebuah organisasi sangat di butuhkan karena dengan adanya perencanaan maka sebuah organisasi bisa berjalan dengan baik. Perencanaan yang telah di lakukan oleh Badan Usaha Milik Desa sebagai dasar awal untuk mencapai tujuan yang ingin di capai.

Didalam organisasi yang baik harus mempunyai program yang baik pula sehingga output nya 
bisa di rasakan oleh masyarakat tentu nya, program-program tersebut harus lah sesuai dengan keadaan masyarakat, harus sesuai dengan keadaan lingkungan sekitarnya sehingga program yang dibuat nantinya tidak akan berjalan sia-sia. Penempatan Tugas dan Fungsi Pembagian kerja atau tugas harus sesuai dengan kemampuan dan keahlian dari masing-masing individu, sehingga pembagian pekerjaan dapat berjalan secara efesien dan efektif. Dalam Badan Usaha Milik Desa (BUMDes) sudah dilakukan penempatan tugas dan fungsi yang sesuai dengan bidang keahliannya masing-masing sehingga para pegawai sudah mengetahui tugas dan peran nya masing-masing sehingga tidak terjadi tumpang tindih didalam pekerjaannya.

Penggerakan dalam Badan Usaha Milik Desa (BUMDes) selalu adanya bimbingan, saran dan perintah. Di setiap rapat kerja yang tergabung dalam Badan Usaha Milik Desa (BUMDes) tidak cukup tahun atau kurang berpengalaman sehingga diperlakukannya bimbingan agar apa yang menjadi kekurangan bahkan kendala dalam Badan Usaha Milik Desa (BUMDes) dapat diperbaiki dengan saran yang membangun bahkan selalu memberikan motivasi agar pengurus bekerja lebih giat dan kerasagar tercapainya tujuan dari Badan Usaha Milik Desa (BUMDes) tersebut, itulah bentuk motivasi yang lakukan.

Evaluasi merupakan proses untuk menerapkan pekerjaan apa yang telah dilaksanakan, menilainya dan bila perlu mengoreksi dengan maksud supaya pelaksanaan pekerjaan sesuai dengan rencana semula. Pengawasan sebagai proses penentuan, apa yang harus di capai yaitu standar, apa yang harus dilakukan yaitu pelaksanaan, menilai pelaksanaan dan apa perlu melakukan perbaikan sehingga pelaksanaan sesuai dengan rencana.

Hasil kegiatan menunjukkan bahwa lebih dari 50\% peserta sudah menguasai teknik produksi jajan upakara secara benar, dan ada 10 peserta (30\%) sudah mampu menghasilkan produk jajan sesuai standar kualitas.

\section{SIMPULAN}

1. Kegiatan desiminasi ipteks dalam produksi jajan upakara telah berjalan dengan baik dan mendapatkan respon positif dari masyarakat dicirikan oleh jumlah peserta yang hadir dan keseriusan peserta dalam mengikuti pelatihan.

2. Partisipasi aktif mitra sasaran dalam seluruh kegiatan desiminasi teknologi cukup tinggi, yaitu rata-rata sebesar 85 persen.

3. Hasil kegiatan menunjukkan bahwa lebih dari $50 \%$ peserta sudah menguasai teknik produksi jajan upakara secara benar, dan ada 10 peserta (30\%) sudah mampu menghasilkan produk jajan sesuai standar kualitas

\section{UCAPAN TERIMA KASIH}

Penulis menyampaikan terima kasih yang sebesar-besarnya kepada Direktorat Riset dan pengabdian Masyarakat Kemenristek Dikti atas dana yang diberikan, Ketua Lembaga Penelitian dan Pengabdian kepada Masyarakat (LPPM) Universitas Udayana atas bantuan fasilitas serta KUBE Br. Kebon Desa Tangguntiti atas partisipasi dan bantuannya dalam pelaksanaan kegiatan ini.

\section{DAFTAR PUSTAKA}

Badan Perencanaan Pembanguanan Kabupaten Tabanan. 2011. Rencana Pembangunan Jangka Menengah Kabupaten Buleleng.

Baiquni, M. 1999. Participatory Rural Appraisal, Metode dan Teknik Partisipasi dalam Pengembangan Perdesaan. Jogjakarta : UGM Press.

Nur Alam La Nafie,Yayu Meiniza Zainiar, Abdul Hamid, Muhammad Tang. 2017. Pelatihan Ketrampilan Manajemen Bagi Pengelola Badan Usaha Milik Desa Tanete Kecamatan Simbang Kabupaten Maros Prosiding Seminar Hasil Pengabdian Kepada Masyarakat (SNP2M) pp.114-117 
Sardiana, I.K., B.R.T. Putri, I.G. Suranjaya, N.L.R. Purnawan. 2015. Pengembangan Kewirausahaan Di Universitas Udayana. Majalah Aplikasi Ipteks Ngayah : Vol. 6, No. 1, pp. 91-101.

Sumodiningrat, Gunawan. 1999. Pemberdayaan Masyarakat dan Jaring Pengaman Sosial. Jakarta : PT.

Gramedia Pustaka Utama. 